\title{
Parents' Roles and Parenting Styles on Shaping Children's Morality
}

\author{
W. N. Tan', Maizura Yasin",* \\ ${ }^{1}$ SJKC Ting Twa, 75200, Malacca, Malaysia \\ ${ }^{2}$ Department of Language and Humanities, University Putra Malaysia, 43400, Selangor, Malaysia
}

Received November 4, 2019; Revised December 30, 2019; Accepted January 15, 2020

Copyright $\bigcirc 2020$ by authors, all rights reserved. Authors agree that this article remains permanently open access under the terms of the Creative Commons Attribution License 4.0 International License

\begin{abstract}
Nowadays, we live in a modern world which has been engulfed by a wave of technology. The changes in the modern world have brought some alterations to our life. The good side brought by the technology is that our life becomes better and better. However, the morality in our children is found deteriorating. Therefore, the paper is going to study, to which extent the parents' roles and parenting styles are in shaping the children's moral development. The data was collected from online database including ScienceDirect, Wiley, ResearchGate, Procedia and Google. Both qualitative and quantitative studies, which were published from year 2009 to 2018 were reviewed systematically and synthesized in a narrative format. The findings of this study were that the parents should play their roles in shaping the children's morality. They should involve themselves in their family, being role models instilling religious beliefs, communicating more often with their children and providing bonding time for their children with their grandparents. For parenting styles, the results showed that the most effective parenting style was authoritative parenting followed by authoritarian. Both the permissive parenting styles were ineffective in encouraging children's morality.
\end{abstract}

Keywords Parenting Styles, Roles, Shaping, Children, Moral Development

\section{Introduction}

Childhood is the paramount period where all concepts of right and wrong should be developed. Their studies have shown that parents started to cultivate moral values in children when the children were 18 to 24 months old (Hammond \& Carpendale, 2014). This demonstrates how early a child should be cultivated with moral values.

There are two types of morality in Piaget's Theory of
Moral Development, which are heteronomous morality and autonomous morality. In heteronomous morality, the children will judge the behaviors as good or bad based on the observable consequences when they enter preschool years (Jambon \& Smetana, 2015). They believe that the rules, which are imposed by the authority such as parents or teachers as unchangeable. This is the stage where their morality starts developing and shaping.

Since the morality of a child starts developing at an early age, parents are the ones who should play their roles in shaping their children's morality as they are closest to the children. However, the modern families are undergoing some transformations in current era of globalization (Langier, 2016). The parents spend less and less time with their children as they are busy pursuing their careers. As a result, the morality among our teenagers is declining (Dalmacito, 2013).

There are numerous researches showing that parents' roles and parenting styles are important in shaping the children's morality. Therefore, this paper is going to examine on how parenting affects the children's morality. By doing so, it hopes to raise the awareness among the parents in shaping their children's morality.

Decadence of morality in the era of 21 st century has reached such an alarming level. As we can see, the young generations nowadays do not show respect to the elders. Moreover, they involve in all kinds of moral problems such as bullying, social problems, vandalism and so on. In addition, there were two teenagers who aged 15 and 19 charged with murdering Nur Amira Abdullah,who was stabbed 45 times with a sharp knife (Silva, 2017). Furthermore, we can see the news about unwanted babies being killed by young mother in the newspaper. These cases are common to be seen or heard in today's world.

According to Youth and Sports Ministry of Malaysia, the study conducted shows that among 5,860 youths, there was $71 \%$ smoking, $40 \%$ watching pornographic videos, $28 \%$ gambling, $25 \%$ consuming alcohol and $14 \%$ taking 
drugs (Dhammananda, 2001). The young generations nowadays are our tomorrow's leaders. If the morality among youths has not been shaped, we will lose our future leaders to rule the world.

Whenever an issue arises, we will start to play the blaming game. Some accuse the parents while some blame the media for not developing the morality among children. In this study, we will focus on the parents as they are supposedly to be the closest person to the children. According to Ms Alice Mwesigwa, most parents are not always there for their children. Consequently, the children will seek advice from their peers and get the wrong elements (Mukombozi, 2014). So, we will look at the roles and parenting styles that should be adopted by parents in developing the morality among children. Once the awareness among parents has been raised, they can carry out their responsibilities in shaping the children's morality. Then, we can have honest, genuine future generations that can build a bright future for our country.

\section{Methodology}

\subsection{Search Strategy}

The published and unpublished studies were searched through the following online database over the period 2009-2018. The database that we searched includes ScienceDirect, Wiley, ResearchGate, Procedia and Google. The keywords that we used to search for the studies in the database include parenting styles, roles, shaping, children and moral development. There was no language restriction in the studies we found. The studies might be using English or Mandarin languages as long as the studies are related to the children's morality.

\subsection{Selection Criteria}

The inclusion criterion was the included studies must have been published in the last ten years which is from 2009 to 2018. The included studies must be about parents and children's morality.

\section{Data Collection and Analysis}

From the research we have found, there was a research conducted to examine the responsibility for the moral education of the child (Oladipo, 2009). The result reported that every single institution plays a role in shaping the children's morality. The institutions mentioned in the research include parents, teachers and religious institutions. The morality of the children cannot be shaped by depending on any single institution solely. With the cooperation between the institutions, the child will have a meaningful moral education.
Another study was conducted to find out the relationship between parenting and delinquency (Hoeve et al., 2009). They did a meta-analysis on 161 published and unpublished manuscripts. In the study, it was reported that there was a significant relationship between parenting and delinquency. Parental monitoring, psychological control and negative aspects of support were the strongest links that lead to delinquency. Besides that, the research had provided an insight on support by fathers that was larger than mothers. Therefore, the researchers suggested that fathers should be involved in intervention programs for youth delinquency.

Melati, Zaharah and Saedah (2010) carried out a qualitative study to investigate the factors that contribute to children's moral development and academic achievement. The participants in the research were 20 parents whose children excel academically in public examination. They were interviewed and the data were coded. From the interview, the factors that contribute to children's academic achievement and moral development were "diet", "genetic", "commitment", "positive perception" and "religiosity".

In the study of Thomas (2011), he used 290 adolescents who were aged 13-19 as his participants. The study aims to find out the relationship between adolescent moral values and adolescent delinquency. The findings reported that parent and peer contexts were the most influential factors in adolescents' delinquency. Besides that, the researcher also introduced how parents and peer contexts affect adolescents' moral development. Dalmacito (2013) had conducted a research to find out the causes of moral decline in teenagers. He reported the same findings as Thomas, which is peer pressure and poor family involvement in contributing the moral decline among teenagers. On top of that, Dalmacito also pointed out mass media as one of the reasons. He suggested that the educators use the contextual theology in improving the teenagers' morality at the end of his study.

Adnan, Arifin and Borhan (2014) conducted a research to identify the obstacles that hinder the moral development of adolescents in Malaysia. The role of educational institutions was focused in the tenth Malaysian plan. However, the role of parents was ignored. Therefore, they planned to find out the factors that can minimize the morality problem among adolescents. There were 362 Malay working parents who took part in the study. The parents were asked to complete the questionnaire which is made up of two parts. One part is to measure the level of parents' awareness while another part is to measure parents' practice. At the end of the study, the researchers reported that in order to protect adolescents from the agents of moral decline, parental awareness should be raised.

The study was further supported by Danielle (2014) who mentioned parental socialization had an impact on children's moral behaviors. If there is parental awareness 
in shaping the children's morality, then the parents should socialize with their children more often. It was reported that there were various kind of socialization practices among parents. The parents would choose which practice to be used depending on the situation and the child's characteristics. The interaction between mother and child aims to socialize the child. At the same time, the children would exert their influence on the mothers as well. This is one of the highlights in the study.

In Nairobi County, Kenya, the study was conducted to find out the influence of parental characteristics on pre-school children's moral development (Kiare, 2015). A correlation research design was employed. There were 15 pre-schools involved in this study and a sample of 60 parents was obtained. The study reported that parents' socio-economic status has the biggest impact in influencing pre-school children's moral development. Then, the children's moral development was affected by parents' level of education, age and family structure too. The parents should keep an eye on their children's behavior and correct them immediately if there is any misbehavior. Besides parents, the whole schools' stakeholders have responsibility in ensuring the children's morality.

Since the morality of children is deteriorating, there was a study carried out to investigate the reasons of deterioration in the family at the urban side of Lahore city (Sonia, Syeda \& Sadia, 2015). Focus group discussion method had been employed in the study. The findings had reported a few factors that lead to the moral decay among the children. First, the parents in the families ignored the primary social institution of religion to avoid their children to become religious fanatics. Besides that, the girls were supposed to study religious teaching rather than men due to the gender discrimination. Furthermore, the parents themselves showed less interest in religion. Finally, the grandparents' influence had been identified as one of the factors that contributed to the deterioration of morality. The parents had kept children away from their grandparents. However, the study reported that the grandparents' influence would bring a positive impact on children.

Ansari and Gershoff (2015) carried out a research to investigate to which extent the parent's involvement in Head Start programs can bring changes in both parents and children. A representative sample of 1020 children who aged three years was used in the study. Head Start was an early childhood program which focused on two-generation approach. The approach focused on both children and parents. At the end of the study, the researchers found out that the parents who were involved in Head Start programs showed an increase in cognitive stimulation. At the same time, they decreased their spanking and controlling behaviors. With these changes in parenting, the children's academic and behavioral skills had improved a lot indirectly.
Sarwar (2016) in his study aimed to find out the impact of parents and their parenting styles on the children's moral development. An in-depth interviews approach was used in the study. The interviews were conducted with two mothers of children with delinquent behavior. After analyzing the data, it was reported that the authoritative parenting style is more effective for children than authoritarian style. The authoritarian style leads the children to be rebellious and in turn create a lot of problems. Besides that, the findings also revealed that the parents should spend more time with their children in order to reduce their problematic behaviors.

Sarwar's result was further supported by Zubaideh and Khan (2016) in his study to find out the relationship between parenting styles and moral development of children from 4 to 6 years old. The setting was in kindergartens of Babol city. Parenting style questionnaire Baumrind and inventory moral judgment questionnaire were used to collect data. It was reported that there was a significant relationship between authoritative and authoritarian style and children's moral development. Those children from authoritative families were reported to have a higher mental health and self-esteem while the children from authoritarian families had the lowest level of empathy.

Langier (2016) discussed about the family's factors that lead to the moral depravity of younger generation in the context of modern families. In the modern families, the parents would delegate their duties to the others because they were too busy pursuing their careers. It's hard for proper educational influence to take place. Besides that, lack of parents as the role models was another factor. Family breakdown and remarriages were common phenomenon in modern families and had an impact on the child. Last but not least, the limitation of contact between grandparents and grandchildren was reported to have a negative effect on children's development.

Johnson (2016) studied about four types of parenting styles in his paper. The factors which had been identified in permissive and authoritarian parenting style were poor parenting practices, inattentive monitoring, weak parent-child bonds, rejection and so on. These factors were significant in prediction of criminality. The researcher stressed on full attention to parenting styles in order to decrease antisocialist behavior among youths. The authoritative parenting was found to be the most effective style followed by the authoritarian while the permissive parenting style failed in encouraging morality.

The parental practices and the characteristics of parent-child relationship in shaping the behavior, moral affect and cognition in children were investigated (Soorya $\&$ Sunil, 2018). The parenting practices, such as discipline, conversations and modelling should be used by the parents in teaching the moral codes and standards. The most effective parenting style reported was the use of authoritative style which the moral values could be 
internalized.

\section{Discussion}

\subsection{Parent's Roles}

\subsubsection{Involvement}

From the research conducted in year 2009, it talks about the responsibility in shaping children's morality. We know that the children's morality cannot be a sole responsibility for an institution. Instead of that, the school and religious institutions should work together with the parents to shape the children's morality. Besides that, paternal support is more important than maternal support in preventing delinquency. This best explains why the child raised in single parent's families is found more problematic than those who grew up in intact family in society nowadays.

Besides that, the parents believed that "diet", "commitment", "positive perception" and "religiosity" are important factors in contributing to children's moral development and academic achievement. From the research, we know that parents should play a role in preparing the children's diet in order for them to eat and grow healthily. Moreover, the parents should engage themselves in their children's education and have belief in their children. Finally, the parents must train their children to perform prayers five times daily as they believe religiosity plays an important role in shaping high morality.

As the society develops, the role of parents was ignored gradually. Even in the Malaysia Education System, the focus of shaping morality relies on the educational institution solely. It is contradicting with the research carried out in previous years, which stated that every single institution should play a role in developing the children's morality. Nowadays, some parents have children because of their belief about prestige, life satisfaction and important investment (Langier, 2016; Din, Ayub, \& Tarmizi, 2016).). The parents treated their children as a tool to fulfill their dreams. Therefore, they start to delegate their duties to other parties, like school's authority or tuition center teachers. However, both the parties are only able to deliver the knowledge, but not shape morality. The parents and children's bonding time is an important factor in shaping the children's morality. As stated by Langier (2016) in the study, young people's emotional instability and moral confusion are due to the weak bonds with the family members. So, the parents should spend more time to bond with their children in order to develop their moral development.

\subsubsection{Role Models}

Besides "commitment", "positive perception" and "religiosity" factors in shaping children's morality, the parents believed "genetic" has an impact in developing the children's morality and academic achievement as well. The genetic discussed here is not referring to the biological term but through modeling and imitation. Some parents claimed that their siblings excelled in their academic achievement and are university graduates. So, they show high morality at home. The children will learn the importance of academic success. At the same time, they will imitate their good behaviors too. The study reported that some participants who have witnessed the kind and selfless behaviors undertaken by family members will imitate the kind acts too (Mattis et al., 2009). Therefore, it is important for the parents or uncles to be well-behaved and become the role models to the children.

The lack of right role models among the parents has led to the moral depravity among the young generation (Langier, 2016). Parents are the first role models to whom the children can imitate. The children's personal moral development will start at home based on the rules and moral principles in the family. The children will observe the family's activities and follow certain patterns of their family's behaviors. The children used to observe and imitate certain behaviors based on Bandura's Observational Learning Theory (McLeod, 2016). Therefore, it is crucial for the parents to show good behaviors and be role models to their children.

\subsubsection{Religiosity}

Parents can influence their children's moral development through some pathways. One of them is by instilling religious beliefs to the children. The studies prove that parents' moral values that were passed on to their children can help to develop the their children's morality (Melati,et al., 2010). However, the urban families failed in providing religions and moral education to their children. A few factors have been identified in the study (Sonia, et al., 2015). First, the parents from urban families in Pakistan might be afraid that their children might become religious fanatics. Besides that, the urban children are more stubborn to follow their parents' instructions as they want freedom. In addition, the parents themselves have less interest in religion and ignore all religious rituals. This is due to the materialism and preference to modern way of life.

The social learning theory shows that modelling is effective in shaping children's moral judgment responses (Soorya \& Sunil, 2018). Therefore, in order to shape high morality among the children, the parents must have strong religious beliefs. Then, they can instill religious beliefs to their children. Besides that, they should carry out the religious rituals. If the parents are Muslims, they have to perform prayers five times a day. The children will observe and imitate their parents' behaviors based on Social Learning Theory. Religiosity is said to be an important determinant of high morality (Melati, et al., 
2010). In Malaysia's National Principles, 'Belief in God' appears to be the first principle. It shows how important the religious beliefs should be cultivated in our life. Hence, the parent should play their role in instilling religious beliefs to their children. At the same time, they must have strong religious beliefs too.

\subsubsection{Communication}

The moral representations of parents are often passed on to children through socialization techniques. Conversations between parents and children can contribute effectively in the moral development of the child (Wainry \& Recchia, 2014). Therefore, as parents, they cannot be busy pursuing their careers. Instead of that, they should spend more time to communicate with their children. During the conversation, the parents can deliver some moral messages to their children. They might explain the effect of child's action on others and motivate reparative behaviors (Wainryb \& Recchia, 2014). Besides that, they can express their disappointment towards the child's behaviors. A considerate child would spare on parents' feelings and won't repeat the misbehaviors. In addition, the parents can listen to their children's problem and guide them in solving their moral dilemmas. Parents-children discussion about moral issues is useful in instilling the parent's beliefs into the child's belief system and has a positive impact in shaping the child's pro-social behaviors (Johnson, 2016).

Moreover, reminiscing conversations between parents and children can help to foster the children's internalization of values. Reminiscing conversation refers to the dialogue about a past transgression. During the conversation, the parents can convey some moral messages to the children. The children are more likely to accept the moral messages when there is a lack in emotional arousal. With the conversation with parents, the children can feel the concerns and warmth. This indirectly guides the children to the correct path to develop their moral development. Therefore, it is important for the parents to spend time to socialize with their children.

\subsubsection{Provide Bonding Time for Children with Their Grandparents}

Most of the modern parents are busy with their work and have no time for their children. However, they would think that the older generation is old-fashioned and they are not able to raise the children in a modern way. Therefore, the parents nowadays prefer to send their children to the young people who work as babysitters (Langier, 2016).

Actually, this is one of the misconceptions among the parents. The researchers agreed that grandparents can work as an institution to develop children's strong morality. They could bring positive impacts on the children by narrating old bedtime stories (Sonia, Syeda \& Sadia, 2015). In Chinese family, the older people are treated as a treasure. They are experienced teachers in life and know what their own educative mistakes are. Hence, they are able to teach their grandchildren on how to perceive others' needs, respect or tolerance in a better way. Besides that, the grandchildren's moral attitudes can be shaped through the grandparents' teaching. Therefore, the parents should play a role in allocating time for their children to interact with their grandparents. I am sure the grandparents would feel happy as well.

\subsection{Parenting Styles}

\subsubsection{Authoritarian Parenting Style}

The parents in authoritarian style show demandingness and are less responsive to the child's needs. They like to exert their power on the children and ask them to do whatever things that have been told without any reasons. They seldom invite their children to have moral discussion. This kind of parents might show some degree of warmth towards their children but demand respect from their children.

The children who are raised under authoritarian parenting style may have higher level of antisocial behaviors. They tend to be more discontented and withdrawn due to the parental hostility and rejection. So, some of them might commit crime when they grow up. However, some research finds this kind of parenting style is good for Blacks because of their lower social-economic status and dangerous neighbor.

\subsubsection{Authoritative Parenting Style}

Authoritative parenting style is the most effective in developing the children's morality. The children who were raised within this style tend to show pro-social behaviors and are able to reason autonomously about moral problems. Besides that, they will respect the adults. In addition, they are more self-reliant, self-controlled and self-confident.

These outcomes are resulted from the way their parents educate them. The authoritative parents always show responsiveness to their children's needs. Furthermore, they will keep an eye on their children's behaviors and discipline based on reasoning. They may provide emotional support to their children but with strict behavioral supervision. Therefore, the children are found less involved in criminal behaviors in adulthood.

\subsubsection{Permissive Parenting Style}

There are two types of permissive parenting style, which are permissive indulgent parenting and permissive neglectful parenting. The permissive indulgent parents show high level of responsiveness but lack of demandingness towards their children while permissive neglectful parents have minimal warmth and control over their children.

In permissive indulgent parenting, the parents have 
little control over their children. They will treat their children as friends and so, they are liked and accepted by their children. Besides that, the children are allowed to decide things on their own without any guidance provided by permissive indulgent parents. This type of parenting style sounds good but actually, the children's moral development is limited. Since the children are less controlled by the parents during childhood, they will face problems in following the rules and resist supervision by the others. In addition, they are immature and have higher level of psychological maladjustment. Therefore, they have a higher possibility to involve themselves in antisocial behaviors if compared to those who grow up with authoritative parenting style.

The permissive neglectful parents do not carry out their parenting responsibilities properly. They will just provide the children with physical necessities but not concerns and love. They might think the children as taxing and inconvenient. Besides that, the children are being ignored or rejected at most of the time. The children are seen but not heard about their ideas, problems or feelings. So, the children will experience depression and have antisocial personality. The study also reported that the children who were raised with permissive neglectful style are always associated with higher criminal for Blacks (Johnson, 2016).

In my point of view, I think the permissive neglectful parenting style is the most destructive and brings the most negative impacts on the children. Although there are weaknesses in authoritative, by the authoritarian and permissive indulgent parenting styles, the children can still feel love and concerns from their parents. However, the children who were raised with permissive neglectful parenting style are just ignored by the parents. In Maslow's Hierarchy of Needs, there are five stages of growth in humans which are physiological needs, safety, love or the belonging, esteem and self-actualization (McLeod, 2018). The children who were raised with permissive neglectful style might reach the physiological needs stage but definitely not love or belonging stage. If there is a lack of love or sense of belonging, how can we expect the children to show love to the others and have high morality? The answer is definitely " No"! Therefore, the parents should be careful in adopting the appropriate parenting style to develop their children's moral development.

\section{Conclusions}

The deterioration of children's morality may cause the socio-economic problems in country. So, moral development should be developed during childhood in order to produce compassionate and emotional human beings. To children, family is the first place which creates the bond between them with the environment. Besides that, the children will start to shape their norms of behaviors and attitudes at home too.

Parents are the ones who first appear in children's lives. Therefore, they should play their roles in inculcating moral values to their children. The study highlights the various roles in which parents should play to shape their children's morality. As parents, they are the closest person to the children. So, there should not be any reasons for them to delegate their roles to other parties because psychological abuse can bring negative impacts developmentally on children. At home, they must spend time and engage themselves in educating their children. The stronger the bond between parents and children, the higher morality is found among the children.

In addition, the parenting styles should be focused in order to develop the children's morality and decrease antisocial behavior among the youths. Authoritative parenting is discovered to be the most effective parenting style with authoritarian coming in second. Both permissive parenting styles are ineffective in shaping the children's morality. The permissive and authoritarian parenting styles might contribute to the criminality among juveniles. The factors identified in the permissive and authoritarian styles are poor parenting practices, emotional negativity, weak parents-children bonds and so on.

In conclusion, the parents must be responsible in playing all the roles in shaping the children's morality. In order to have a child, they should be mentally and physically prepared because it is not easy to educate a child. Moreover, the parents have to think twice before adopting the most appropriate parenting style. The parents might adopt a predominant use of authoritative style but from time to time, they can change the parenting techniques to cater to the developmental needs of the child. As parents, they should be flexible in choosing the parenting style. With the awareness and concerns from the parents, the children's moral development can definitely be developed and shaped. So, we can expect to have a well-mannered society.

\section{REFERENCES}

[1] Adnan, A.R., Arifin, M., \& Borhan, I.. Barriers to moral development of adolescents and parental responsibility: The case of Malay working parents. International Journal of Humanities Social Sciences and Education, 1(6), 40-48, 2014.

[2] Ansari, A., \& Gershoff, E. Parent involvement in Head Start and children's development: Indirect effects through parenting. Journal of Marriage and Family, 78(2), 562-579, 2015

[3] Dalmacito, A.C.Jr.. Moral decline in teens: The application of contextual theology. Asia-Pacific Social Science 
Review, 13(2), 24-40, 2013.

[4] Danielle, P.O. Parental socialization of moral behaviors in the context of poverty. Philippine Journal of Psychology, 47(1), 41-72, 2014.

[5] Dhammananda, V.K.S. (2001, November 15). Human life and problems, 2001. Retrieved from https://www.budsas.org/ebud/life/life-04.htm

[6] Din, N.M, Ayub, A.F.M \& Tarmizi, R.A (2016). Influence of parental involvement and peer support on mathematics engagement among Malaysian secondary school students. Malaysian Journal of Mathematical Sciences. 10(S) 175-185.

[7] Hammond, S., \& Carpendale, J. Helping children help: The relation between maternal scaffolding and children early help. Social Development, 24(2), 367-383, 2014.

[8] Hoeve, M., Dubas, J.S., Eichelsheim, V.I., Van Der Laan, P.H., Smeenk, W., \& Gerris, J.R.M. The relationship between parenting and delinquency: A meta-analysis. Journal of Abnormal Child Psychology, 37(6), 749-775, 2009. doi: 10.1007/s10802-009-9310-8

[9] Jambon, M., \& Smetana, J. G. Moral Development, theories of. International Encyclopedia of the Social \& Behavioral Sciences, 788-795, 2015. doi:10.1016/b978-0-08-097086-8.23201-7

[10] Johnson, S.A. (2016). Parenting styles and raising delinquent children: Responsibility of parents in encouraging violent behavior. Forensic Research \& Criminology International Journal, 3(1), 81, 2016. doi:10.15406/frcuj.2016.03.00081

[11] Kiare, J.W. Influence of parental characteristic on Pre-school children's moral development in Nairobi Country, Kenya, 2015 (Master dissertation). Retrieved from

http://erepository.uonbi.ac.ke/bitstream/handle/11295/9280 4/Kiare, $\% 20$ Jacqueline $\% 20 \mathrm{~W}$ Influence $\% 20 \mathrm{of} \% 20$ parent al $\% 20$ characteristics $\% 20$ on $\% 20$ pre-school $\% 20$ children $\% 2$ 0s\%20moral\%20development $\% 20$ in $\% 20$ Nairobi\%20count $\mathrm{y}, \% 20$ Kenya.pdf? sequence $=3$

[12] Langier, C. Moral upbringing of children in the context of transformations of modern families: An overview of issues. ZeszytyNaukoweWyższejSzkołyHumanitas. Pedagogika, (12), 147-157, 2016.

[13] Mattis, J.S., Hammond, W.P., Grayman, N., Bonacci, M., Brennan, W., Cowie, S.A., \& So, S. The social production of altruism: Motivations for caring action in a low-income urban community. American Journal of Community Psychology, 43(1-2), 71-84, 2009.

[14] McLeod, S. Bandura- Social Learning Theory. 2016 Retrieved https://www.simplypsychology.org/bandura.html

[15] McLeod, S. Maslow's Hierarchy of Needs. 2018. Retrieved from https://www.simplypsychology.org/maslow.html

[16] Melati, S., Zaharah, H., \& Saedah, S. Factors contributing to academic achievement and moral development: A qualitative study. The International Journal of Research and Review, 5(2), 18-23, 2010.

[17] Mukombozi, R.. Youth immorality blamed on parents.
Daily Monitor, p.1. 2014. Retrieved from https://www.monitor.co.ug/News/National/Youth-immoral ity-blamed-on-parents/688334-2534582-vt5ivlz/index.html

[18] Oladipo, S.E. Moral education of the child: Whose responsibility? Journal of Social Sciences, 2(20), 149-156. 2009.

[19] Sarwar, S. Influence of parenting style on children's behaviour. Journal of Education and Educational Development, 3(2), 222, 2016.

[20] Silva, J.E.D.. Teens charged with murder of girl who was stabbed 45 times. The Star Online, p.1. 2017, December 29 Retrieved from https://www.thestar.com.my/news/nation/2017/12/29/teens -charged-with-murder-of-girl-stabbed-45-times/

[21] Sonia, O., Syeda, M.H., \& Sadia, J.The role of family in teaching religious and moral values to their children in urban areas: A case study of Lahore (Pakistan). Academic Journal, 16(1), 258-272, 2015.

[22] Soorya, S., \& Sunil, K.V. Moral socialization: The role of parents. IAHRW International Journal of Social Sciences, 6(1), 165-170, 2018.

[23] Thomas, A.M. (2011). Parent and peer influences: Their role in predicting moral values and delinquent behavior (Master dissertation)., 2011 Retrieved from https://mountainscholar.org/bitstream/handle/10217/47412 /Thomas colostate $0053 \mathrm{~N}$ 10365.pdf? sequence $=1$ \&isAllo wed $=\mathrm{y}$

[24] Wainryb, C., \& Recchia, H. . Parents-child conversations as context for moral development. In $\mathrm{C}$. Wainryb and $\mathrm{H}$. Recchia (Eds.), Talking about right and wrong: Parent-child conversations as contexts for moral development (pp. 3-18,. 2014. Retrieved from https://www.researchgate.net/publication/264788433_Pare nt-child conversations as contexts for moral developme nt_Why_conversations_and_why_conversations_with_par ents

[25] Zubaideh, B., \& Arsalan Khan, M.O. Investigate the relationship between parenting styles with development of moral judgment in children 4-6 years in kindergarten of the city of Babol. Mediterranean Journal of Social Sciences, 2016. doi: 10.5901/mjss.2016.v7n2s2p92 